By IDA R. MILES

\title{
Scientific Collections in the
}

\section{University of Tennessee-Oak Ridge Area}

W ITHIN THE PAST twelve years there has been a great increase in the scientific literature resources available in the Knoxville-Oak Ridge area of Tennessee. During this period of time, extensive additions have been made to the science collections at the University of Tennessee Library, and large specialized libraries have been built up in Oak Ridge at the National Laboratories, the Gaseous Diffusion Plant, and the Institute of Nuclear Studies. Individually, these libraries can be proud of their holdings; collectively, they encompass a notable selection of scientific literature. The publication of Charles Harvey Brown's Scientific Serials ${ }^{\mathbf{1}}$ and the compilation by the Oak Ridge Chapter of the Special Libraries Association of a union list of scientific serials in the region $^{2}$ have provided an excellent opportunity for evaluation of holdings.

Following World War II, the University of Tennessee underwent a period of rapid increase in enrollment and an important expansion of its teaching and research programs at the graduate level. Enrollment, which had reached a prewar high of 3,834 in $1940 / 41$, then skidded to 1,894 in $1943 / 44$, began a sudden rise in $1945 / 46$, reaching the postwar high of 9,045 students in $1947 / 48$. The present enrollment of over 7,500 is almost twice that of the highest prewar year.

During this period of greatly increased

1 C. H. Brown, Scientific Serials (Chicago: Association of College and Reference Libraries, 1956), $189 \mathrm{p}$.

${ }^{2}$ Special Libraries Association, Oak Ridge Chapter, Union List of Serials in the Technical Libraries of the Oak Ridge-Knoxville Area (3d ed.; Oak Ridge, Tenn., 1957).

Miss Miles is Science Librarian, University of Tennessee. enrollments there came a demand for the establishment of graduate programs leading to the Ph.D. degree. Approval of the doctoral program in chemistry had been granted in 1943. The Ph.D. program in physics was begun in the fall of 1946, and one in mathematics in the fall of 1947. During the $1948 / 49$ school year the other science departments-botany, bacteriology, zoology and entomology, and geology--were given permission to offer courses leading to the Ph.D.

The growth of the University was reflected in the growth of the Library. The great increase in number of students necessitated tremendous quantitative increases in the size of the Library. Much more important, the rapidly expanding program of graduate work demanded qualitative increases in the science holdings. Unquestionably, the basic scientific journals must be available. Need for many of these titles was common to several of the sciences, but beyond this common need, the materials necessary for research varied according to the subject. Physics was chiefly concerned with recent journals; mathematics needed the nineteenth-century literature as well as that of the twentieth century. Chemistry could fairly well limit its requests to a group of essential items, while the needs in botany and zoology were widely diversified.

In its program of acquisition, the University Library tried to balance the immediate need for an availability of the recent literature with the sometimes less obvious need for back files of important older journals. Frequent reference was made to the earlier lists of most-cited periodicals for an indication of the im- 
portance of journals being considered for purchase. Such statistical studies were then checked against, and supplemented by, recommendations of a group of interested faculty members who have made valuable suggestions over the years with respect to the immediate and long-term needs in their subjects. Extensive purchases of scientific serials have been made annually since the mid-1940's. In the past two bienniums, the University administration has made sizable grants to supplement the annual book appropriations and to permit acquisition of much needed research materials.

The major portion of the University Library's science collection is housed in the Science Library and its Biological Sciences branch. Centrally located near the departments it serves, the Science Library is in the Chemistry Building, only a few steps from the buildings housing the mathematics, physics, and geology departments, and within easy reach of the biology and engineering departments. The Biological Sciences Library is in the Biology Building, headquarters for the bacteriology, botany, and zoology departments. Both libraries are under the supervision of the Science Librarian. Reference and information service in the sciences can be furnished from the Science Library, where the card catalog shows a complete record of all science and technology holdings on the university campus. The union card catalog of books in the Oak Ridge libraries is also housed in the Science Library, supplementing the book-form union list of scientific serials in Oak Ridge and Knoxville libraries.

The libraries at Oak Ridge have had a phenomenal growth. The end of World War II found the several government laboratories at Oak Ridge with no central library-only collections of books scattered about in the laboratories. By 1946 both the Oak Ridge National Laboratories and the Oak Ridge Gaseous Diffusion Plant had established central libraries and were beginning a monumental program of acquisition. But even while concentrating on their extensive acquisition program, they still depended heavily on the University of Tennessee Library for loans. At one time in the late 1940's one University Library assistant was occupied full-time in handling the requests for loans from Oak Ridge alone. The ratio of loan between the libraries has been as great as one hundred loaned to one borrowed by the University. The present ratio is about four to one. This ratio seems high in view of the fact that the National Laboratory Library and its branches have surpassed the University's science collection in size, and now contain some 70,000 volumes, while the Gaseous Diffusion Plant Library numbers about 24,000 volumes. Actually, the present ratio of science materials loaned and borrowed is probably about equal, with the other loans being in related fields of interest which do not come within the scope of these special libraries.

The Oak Ridge Institute of Nuclear Studies was established in 1946, an interuniversity venture for the promotion of research and instruction in the nuclear sciences. Almost immediately, the University of Tennessee entered into a contract with the Institute to give formal graduate instruction at Oak Ridge leading to the master's and doctor's degrees in chemistry, physics, and mathematics. Chemical engineering has since been added. The ORINS Technical Library was started in 1948 as a textbook library for these courses, and was administered for a year by a member of the University Library staff. In June of 1949 a librarian was employed by ORINS; the Institute Library and the AEC Technical Library were consolidated under Institute management; and the library began a definite program of development towards becoming a full-scale research library. This library now has some 26,000 volumes. Special attention is given to litera- 
TABLE I

Most Frequently Cited Serials in Eight Sciences

\begin{tabular}{|c|c|c|c|c|c|}
\hline \multirow[t]{2}{*}{ - } & \multirow[b]{2}{*}{$\begin{array}{c}\text { Total Number } \\
\text { of Titles on } \\
\text { List }\end{array}$} & \multirow[b]{2}{*}{$\begin{array}{c}\text { Total Number } \\
\text { of Citations } \\
\text { to These } \\
\text { Titles }\end{array}$} & \multicolumn{3}{|c|}{ Titles Not at U.T. or Oak Ridge } \\
\hline & & & $\begin{array}{c}\text { NUMBER OF } \\
\text { TITLES }\end{array}$ & $\begin{array}{l}\text { NUMBER OF } \\
\text { CITATIONS }\end{array}$ & $\begin{array}{l}\text { PER CENT } \\
\text { OF TOTAL } \\
\text { CITATIONS }\end{array}$ \\
\hline $\begin{array}{l}\text { Mathematics } \\
\text { Physics } \\
\text { Chemistry } \\
\text { Geology } \\
\text { Physiology } \\
\text { Botany } \\
\text { Zoology } \\
\text { Entomology }\end{array}$ & $\begin{array}{r}99 \\
102 \\
101 \\
106 \\
102 \\
107 \\
94 \\
117\end{array}$ & $\begin{array}{r}3,168 \\
9,075 \\
10,052 \\
2,279 \\
5,430 \\
4,135 \\
1,819 \\
1,876\end{array}$ & $\begin{array}{r}2 \\
1 \\
5 \\
15 \\
7 \\
19 \\
24 \\
42\end{array}$ & $\begin{array}{r}14 \\
11 \\
66 \\
175 \\
110 \\
203 \\
382 \\
573\end{array}$ & $\begin{array}{r}.44 \\
.09 \\
.66 \\
7.67 \\
2.03 \\
7.30 \\
21.00 \\
30.50\end{array}$ \\
\hline
\end{tabular}

ture on the applications of nuclear studies in the fields of medicine, agriculture, and industry.

The nature of much of the work done at Oak Ridge has inevitably caused an emphasis, both at Knoxville and at Oak Ridge, on acquisitions in mathematics, physics, and chemistry. Consequently, when a study was made of the holdings of these libraries in the eight sciences reviewed in Scientific Serials, it was these three subjects that showed the greatest bibliographic strength. There are 253 titles on the combined lists for mathematics, physics, and chemistry. ${ }^{3}$ Only eight of these titles cannot be located in the area. Although the libraries do not have complete files of all the journals, the combined holdings show complete sets of more than half of these titles. In most instances where sets are incomplete, only a few volumes are missing, or the missing volumes belong to the nineteenth century literature which is seldom referred to in current chemical and physical research. The eight journals which are lacking furnished less than 1 per cent of the total citations on the lists for each subject.

Perhaps more surprising than the good collection in mathematics, physics, and chemistry, is the high percentage of the

${ }^{3}$ Brown, op. cit., pp. 143-154. physiology titles available. In addition to the need for this material at the University, the Oak Ridge National Laboratory has Biology and Health Physics Divisions, and the Institute of Nuclear Studies has a Medical Division. Of the 102 most-cited titles in physiology, ${ }^{4}$ all but seven are available in the area. These seven titles, all medical journals, furnished only a little over 2 per cent of the total citations. This strong basic collection is especially noteworthy since, as Mr. Brown points out, there is a great scattering of citations in physiology among journals classified in different subject fields. ${ }^{5}$

In the other four subjects which Mr. Brown has studied-geology, botany, zoology, and entomology-the percentage of holdings is not so high. The literature of geology and the biological sciences shows a wide scattering of citations among many journals, making it more difficult to build a basic collection in these subjects than in the "compact" sciences of mathematics, physics, and chemistry. Relatively little work in these subjects is done at Oak Ridge, and the responsibility rests chiefly with the University to increase its holdings. Table I shows the bibliographic strength of the University and Oak Ridge libraries for

4 Ibid.

Ibid., pp. 112-113. 
the titles on the lists of most frequently cited serials in the eight sciences.

Robert W. Orr, writing in Library Trends, has said, "The day will come, if indeed it is not already here, when libraries will be rated less by the completeness of their holdings of serials than by means of a yardstick which takes into account a definitive evaluation of serial holdings both in titles and time spans."6 With this criterion, the Knoxville-Oak Ridge area again rates well in the physical sciences, mathematics, and physiology. Ninety per cent of the citations in physics and chemistry are to the first thirty-seven titles; all thirty-seven are available. Ninety per cent of the mathematics citations are to the first fifty-three titles; all fifty-three are available. In physiology, the first fifty-seven titles supply 90 per cent of the citations; only two of these, ranking twenty-eight and fiftysix, are not available, and both journals lacking are medical journals.

No serious study of Scientific Serials should ignore Chapter IV, "Journals Most Frequently Abstracted."7 Such an investigation of the literature which is currently being made available in abstract form may well be a guide to future purchase, after the basic, most-cited serials have been acquired. Thirty-five of the 119 journals most frequently abstracted in the 1954 Chemical Abstracts do not appear on any of the most-cited lists. Over one-third of these thirty-five are strictly chemical journals; most of the others are general scientific publications or are devoted to special subjects in applied chemistry. Of the 119 titles, thirteen are not being currently received at

'R. W. Orr, "A Few Aspects of Acquiring Serials," Library Trends, III (1955), 399.

${ }^{7}$ Brown, op. cit., pp. 50-56.
Oak Ridge or the University of Tennessee; eight of these thirteen are Japanese publications. Perhaps this should serve as an indicator for future acquisitions.

Most-cited lists can serve only as a beginning, and they have served well at the University of Tennessee Library. The faculty members in most science departments are pleased with the basic collections now on hand. The next concern must be a branching-out, with serious study of what should come next. The needs will vary with the subjects. For example, in physics, present demand at the University is for the many new journals which have been started within the past few years and which continue to spring up. These are chiefly British and American publications. By contrast, in mathematics, demand seems to center around publications from other than the Big Five-the United States, Great Britain, France, Germany, and Russia. Now that the basic journals, as indicated on the most-cited list, are available, there is particular interest in new mathematical publications from Japan and from the countries of southeastern Europe.

The libraries of the Knoxville-Oak Ridge area now have good collections of the most-cited titles in the sciences. These are supplemented by a large collection of other scientific journals, to provide good bibliographic strength in the sciences and technology. Some three thousand titles are listed in the recently compiled union list of serials held by the technical libraries of the area. Although the resources are scattered among several libraries, interlibrary loan relations are extemely cordial and prompt, with daily messenger service between Oak Ridge and Knoxville. The scientific literature is readily available for $u$ se. 